Thorax (1965), 20, 193.

\title{
Thymic tumours with red cell aplasia
}

\author{
A. G. NOR M A N \\ From the Royal Infirmary, Sheffield 6
}

The presence of a thymic tumour in a patient with red cell aplasia was first described by Humphreys and Southworth in 1945. After excision of this tumour the anaemia was cured in this patient. A second case was then recorded by Barquet Chediak, Fuste, and Vázquez Rosales (1953) and again excision was followed by a cure of the anaemia. Fourteen further cases of excision of thymic tumours in patients with pure red cell aplasia have now been described in the literature. This paper reports such a case and reviews the collective results of thymectomy in this condition. These results do not bear out the high promise shown by the first two cases in which relief of the anaemia was recorded.

\section{CASE REPORT}

Mrs. J. H. was 43 years old. She had first come under medical care in 1957. At that time she had a lower abdominal mass which was thought to be fibroids; a chest radiograph showed a mediastinal tumour (Fig. 1). Her haemoglobin was 13.3 g. $/ 100 \mathrm{ml}$., R.B.C. $3,800,000$ cells per c.mm., W.B.C. 13,900 cells per c.mm. She was of difficult personality and discharged herself from the hospital where she was under care in 1957. She remained well until December 1962 when she complained of amenorrhoea and breathlessness of five months' duration.

On examination her haemoglobin was found to be 2.2 g. $/ 100 \mathrm{ml}$. After transfusion, a hysterectomy for fibroids was performed. It was then apparent that

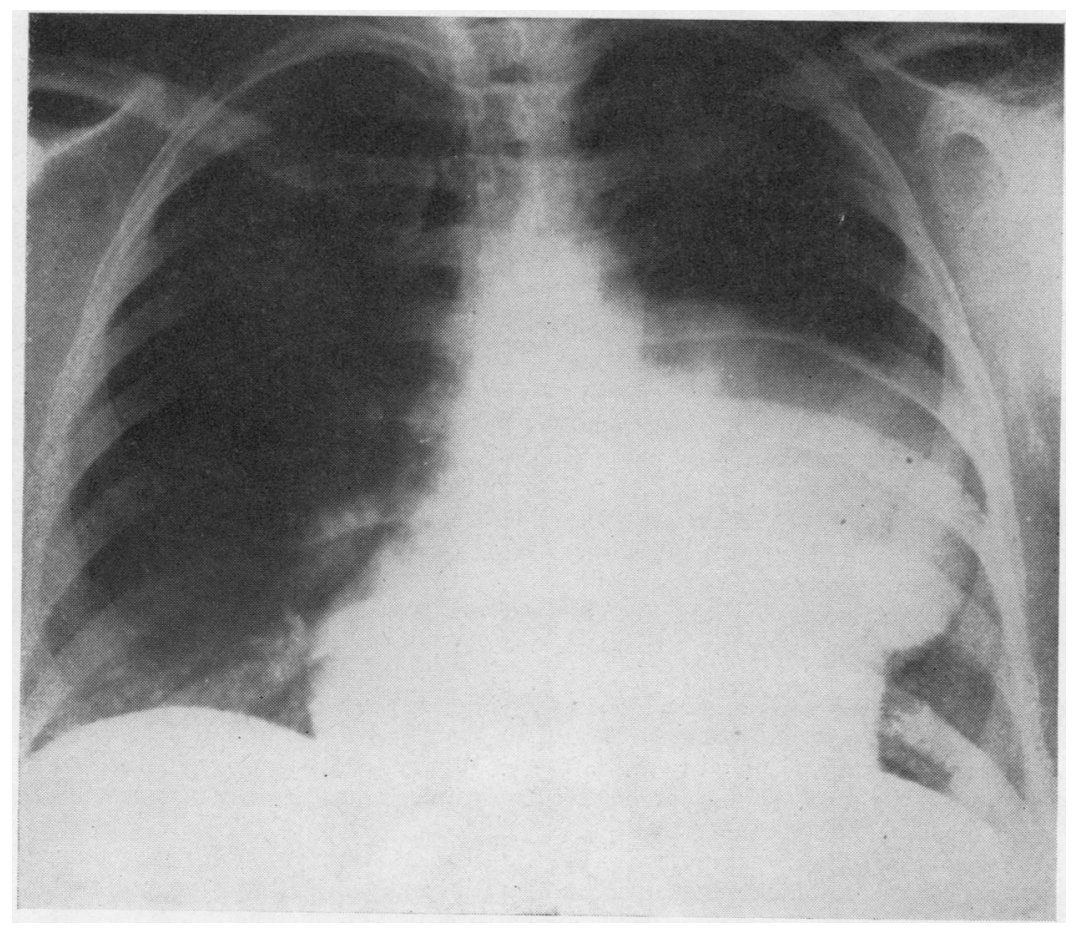

FIG. 1. Postero-anterior chest radiograph, 1957, showing thymic tumour. 


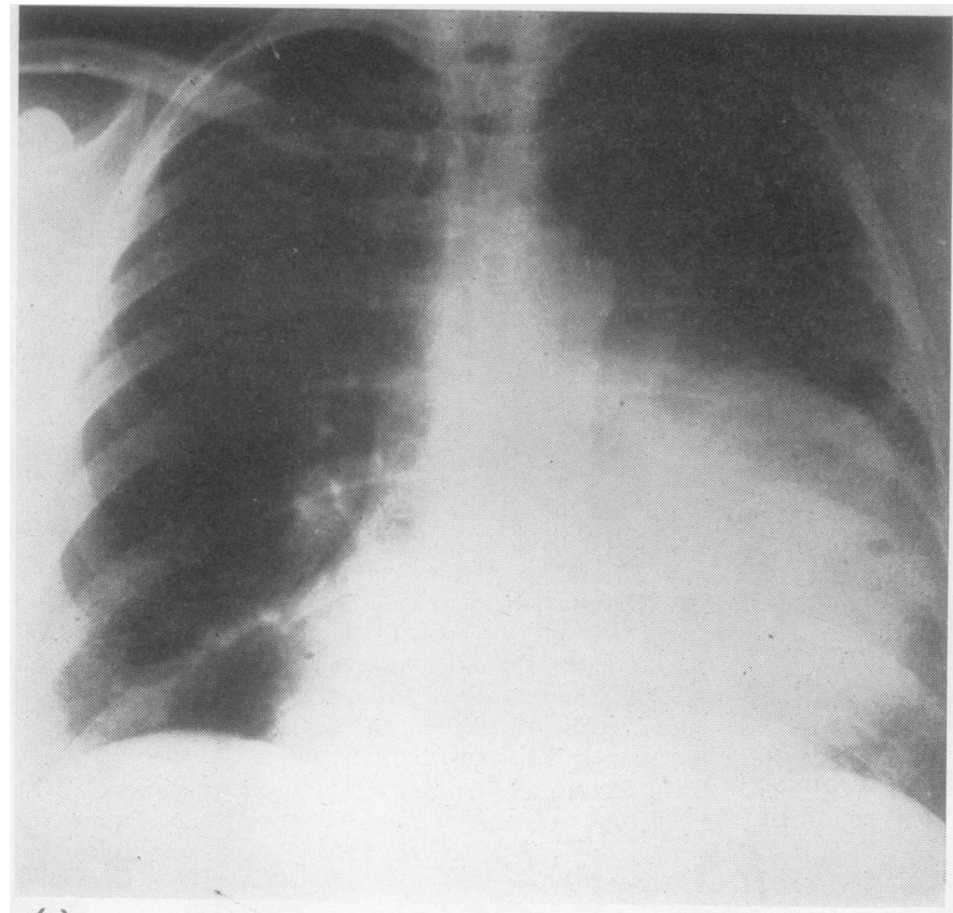

FIG. 2. (a) Postero-anterior chest radiograph, 1963, showing increased size of thymic tumour; (b) lateral chest radiograph, 1963.

repeated monthly transfusions were required to keep her haemoglobin up to a satisfactory level as it fell from about $10 \mathrm{~g} . / 100 \mathrm{ml}$. to $3 \mathrm{~g} . / 100 \mathrm{ml}$. each month without any external blood loss.

Further investigation was therefore carried out which showed the haemoglobin to be $5.9 \mathrm{~g} . / 100 \mathrm{ml}$., W.B.C. 10,000 cells per c.mm., with a differential count of polymorphs $74 \%$, lymphocytes $18 \%$, monocytes $6 \%$, and platelets 240,000 cells per c.mm. Marrow examination showed almost complete red cell aplasia. Serum vitamin B12, $230 \mu \mu \mathrm{g}$. per ml.; direct Coombs' test negative; serum folic acid, $7.9 \mu$. g. per cu.ml. Chromium red cell survival was reduced but there was no concentration of radioactivity over the spleen or the liver. Serum albumin, 3.9 g. $/ 100 \mathrm{ml}$, serum globulin, 1.9 g. $/ 100 \mathrm{ml}$. Paper electrophoresis showed a normal pattern. Chest radiographs showed a mediastinal mass (Fig. 2a and b). This mass was the same as that which was present in 1957 , though it was larger.

On examination this patient was fat with an immature personality. Examination of the chest revealed dullness to percussion anteriorly on the left side of the chest. The liver and spleen were not palpable; there was a lower abdominal scar at the site of her recent hysterectomy. She was anaemic and slightly orthopnoeic. A diagnosis of benign thymoma with red cell aplasia was made.

The patient was treated with prednisolone, $10 \mathrm{mg}$. six-hourly in the first place. This dose was slowly reduced over a period of four months. It produced

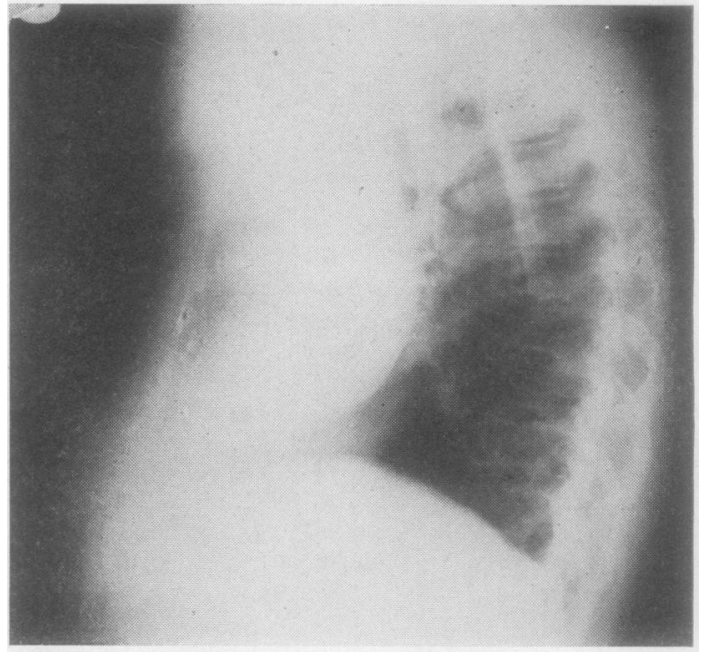

(b)

no action on the anaemia, the patient still requiring multiple transfusions of packed cells during this period. In view of the failure of this treatment it was decided to perform a thymectomy. This was carried out through a left thoracotomy and a large tumour was found in the mediastinum. The tumour was not invading other structures and was excised totally without difficulty (Fig. 3). Post-operatively the patient made a satisfactory recovery from this operation. 


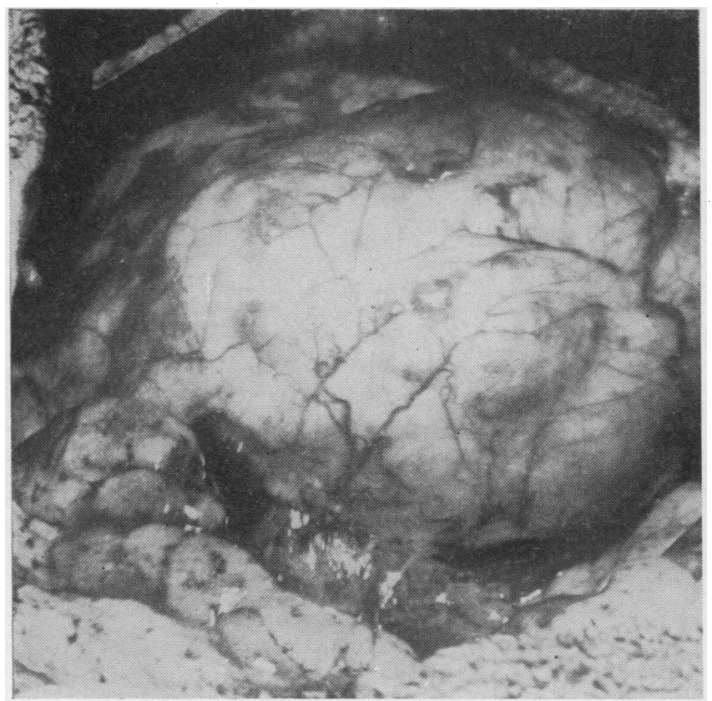

FIG. 3. Thymic tumour in mediastinum, as seen at left thoracotomy.

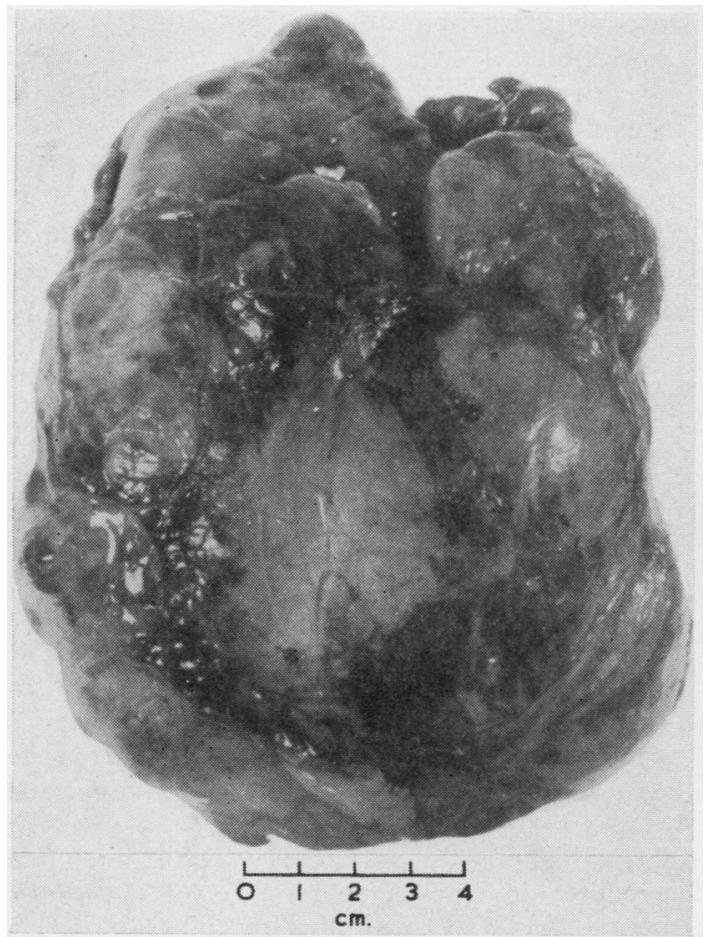

FIG. 4. Excised tumour showing bossed nature.

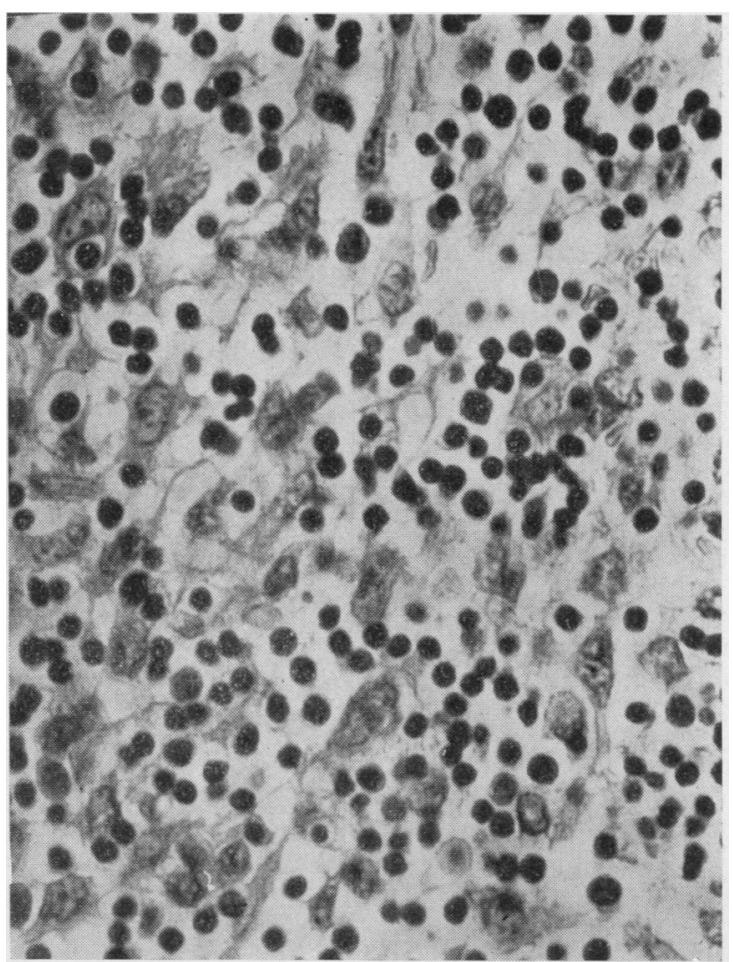

FIG. 5. Photomicrograph of tumour section, showing lymphocytes and epithelial cells $(\times 400)$.

Macroscopically, the tumour was a soft nodular mass measuring $14 \times 11 \times 7 \mathrm{~cm}$. and weighing $560 \mathrm{~g}$. It was covered by a thin, smooth membrane with a few adherent tags (Fig. 4). On slicing, it was composed mainly of homogeneous solid yellowish tissue with peripheral lobulation by fibrous strands. There was some patchy congestion, and areas of tiny cyst-like tissue were present. Histologically, the tumour was a thymoma and showed the characteristic lobular pattern of growth due to intersection by mature fibrous bands. These enclosed cellular masses were composed of an equal proportion of lymphocytes and epithelial cells. In some areas cyst formation had occurred and epithelial cells predominated in the surrounding tissue. As far as could be judged, the capsule was not invaded by tumour, and mitotic figures were not conspicuous (Fig. 5).

After excision of this tumour the patient's blood was regularly examined. Her anaemia remained unremitting, and at no time did reticulocytes appear in the peripheral blood. She required further transfusion with packed cells two weeks after surgery before being discharged home.

Three months later, while having a further transfusion to correct her persistent anaemia, she collapsed and died. 


\section{DISCUSSION}

The association of anaemia with a benign thymoma is being reported more frequently. It is necessary nowadays to divide these blood dyscrasias into four types:

1. A pure red cell aplasia with a normal white blood count, a normal differential count, and a normal platelet count (Humphreys and Southworth, 1945 ; Barquet Chediak et al., 1953 ; and others).

2. A red cell aplasia with a low white count but with a normal platelet count (Bayrd and Bernatz, 1957 ; Ramos and Loeb, 1956).

3. A red cell aplasia with a low white count and a low platelet count (Fisher and Beyer, 1959; Green, 1958).

4. A red cell aplasia with a low platelet count but a normal white count (Bayrd and Bernatz, 1957 ; Jacobs, Hutter, Pool, and Ley, 1959; Stibbe, 1955).

Thymic tumours are also associated clinically with other conditions, namely myasthenia gravis, agammaglobulinaemia, and Cushing's disease. Myasthenia with anaemia and thymoma has been reported by Bakker (1954), and by Chalmers and Boheimer (1954); agammaglobulinaemia with anaemia and thymoma has been reported by Ramos and Loeb (1956). In the past it was assumed that a thymic tumour was the cause of the anaemia and that excision of the tumour would bring relief of the anaemia, as occurred in the first two cases operated upon by Humphreys and by Barquet Chediak. Thymectomy has now been performed on 14 patients suffering from pure red cell aplasia with a normal white blood count and a normal platelet count. Four of these patients were men with an average age of 65 , and 10 were women with an average age of 57. In five of these women the tumour had been noted to be present before the anaemia for a variable number of years, namely, 20, 6, 9,4 , and 4 years.

The results of thymectomy in these 14 patients may be classified as follows:

1. Immediate cure in four patients. Humphreys and Southworth (1945), Barquet Chediak et al. (1953), Bakker (1954), and Jacobs et al. (1959) described an immediate cure after thymectomy, there being a high reticulocyte count in Humphreys' patient 20 days after the operation. However, further investigation shows that these patients had not had a long-term follow-up of success. Bakker's patient died three weeks later of myocarditis, and that of Humphreys one year later of infection. Barquet Chediak et al. report a follow-up of only three months in their patient, and Jacobs reports no follow-up. Thus one patient is known to have been cured for three months and one to have been cured for one year.

2. No response to thymectomy in 10 patients. These were then treated by a variety of methods with variable results.

(a) Steroid therapy after thymectomy: it has been suggested that removing the thymus makes the patient responsive to steroid treatment.

In seven patients the anaemia was unrelenting (Bayrd and Bernatz, 1957 ; Ross, Finch, Street, and Strieder (2), 1954 ; Jahsman, Monto, and Rebuck, 1962 ; Clarkson and Prockop, 1958; Freeman, 1960 ; and present case).

In two patients the anaemia was cured (Parry, Kilpatrick, and Hardisty, 1959; Couespel, Gaillard, and Vaillant, 1960). Parry's patient died 60 days later of septicaemia while cortisone was being withdrawn. Couespel's patient remained well for over one year and is the most successful result recorded.

(b) Steroid therapy after thymectomy and splenectomy: Chalmers and Boheimer (1954) reported one patient who finally responded to adrenocorticotrophic hormone (A.C.T.H.) after thymectomy (which cured an incidental myasthenia gravis) and splenectomy. This patient then remained well for three years but finally died of jaundice and cirrhosis of the liver. In a second patient, remission was obtained by A.C.T.H. after a double operation, but eventually this patient had to be kept alive by multiple tranfusions.

Two other patients have had a thymectomy in whom the red cell anaemia was not pure. One with associated granulopenia, reported by Ramos and Loeb (1956), died immediately after thymectomy. In another, recorded by Lambie, Burrows, and Sommers (1957), thymectomy was of no benefit to an anaemia associated with a low white count and a low platelet count.

Thus thymectomy may raise the blood count immediately in $30 \%$ of these patients with pure red cell aplasia, and may render a further $20 \%$ responsive to steroid therapy. The initial satisfaction with this $50 \%$ success rate must be weighed against the fact that when reviewed over one year later only two patients out of 14 are reported to be well.

The histological pattern is variable within the substance of such a thymoma. All the surgical reports, however, with the exception of that of Jacobs et al., indicate that a benign tumour is present with a pattern similar to that of the one reported in this case. The relationship between the tumour and the anaemia is not understood. In 
five cases, as reported, the tumour had been present for many years before the anaemia developed, and Clarkson and Prockop (1958) report a case in which a thymectomy had been performed two years before the development of the pure red cell aplasia. It appears that the thymoma and the anaemia are both parts of a complicated disease which may be halted in some patients by thymectomy.

\section{SUMMARY}

A case of benign thymoma and pure red cell aplasia is reported. Thymectomy has been recorded 14 times as the treatment for this condition. Immediate relief of the anaemia occurred in four patients, and two more showed a response to steroid therapy which had not previously been present. A one-year follow-up shows that only two patients are maintaining their improvement.

I wish to thank Dr. E. K. Blackburn for referring this case to me, and for performing the haematological investigations.

\section{REFERENCES}

Bakker, P. M. (1954). Enkele opmerkingen bij twee gezwellen van de thymus. Ned. T. Geneesk., 98, 386.
Barquet Chediak, A., Fuste, R., and Vázquez Rosales, G. (1953). Timoma y anemia aplastica. Consideraciones generales. Presentación de un caso. Arch. Hosp. univ. (Habana), 5, 27.

Bayrd, E. D., and Bernatz, P. E. (1957). Benign thymoma and agenesis of erythrocytes. J. Amer. med. Ass., 163, 723.

Chalmers, J. N. M. (1955). Anaemia in patients with thymic tumours (Edit.). Amer. J. clin. Path., 25, 790.

-and Boheimer, $K$. (1954). Pure red-cell anaemia in patients with thymic tumours. Brit. med. J., 2, 1514.

Clarkson, B., and ,Prockop, D. J. (1958). Aregenerative anemia associated with benign thymoma. New Engl. J. Med., 259, 253.

Couespel, R., Gaillard, J. A., and Vaillant, G. (1960). Tumeur du thymus, anémie et hypoplasie érythoblastique. J. frans. Méd. Chir. thor., 14, 617.

Fisher, E. R., and Beyer, F. D. (1959). Thymoma and hemopoietic insufficiency. Arch. intern. Med., 103, 95.

Freeman, Z. (1960). Pure red-cell anaemia and thymoma. Brit. med.J., 1, 1390.

Green, P. (1958). Aplastic anaemia associated with thymoma. Canad. med. Ass. J., 78, 419.

Humphreys, G. H., and Southworth, H. (1945). Aplastic anemia terminated by removal of a mediastinal tumor. Amer. J. med. $S c i, 210,501$.

Jacobs, E. M., Hutter, R. V. P., Pool, J. L., and Ley, A. B. (1959). Benign thymoma and selective erythroid aplasia of the bone marrow. Cancer (Philad.), 12, 47.

Jahsman, D. P., Monto, R. W., and Rebuck, J. W. (1962). Erythroid hypoplastic anemia (erythroblastopenia) associated with benign thymoma. Amer. J. clin. Path., 38, 152.

Lambie, A. T., Burrows, B. A., and Sommers, S. C. (1957). Refractory anemia, agammaglobulinemia and mediastinal tumor. Ibid., 27,444

Parry, E. H. O., Kilpatrick, G. S. and Hardisty, R. M. (1959). Red-cell aplasia and benign thymoma. Brit. med. J., 1, 1154.

Ramos, A. J., and Loeb, V. (1956). Diagnostic problems. Presentation of case. J. Amer. med. Ass., 160, 1317.

Ross, J. F., Finch, S. C., Street, R. B., and Strieder, J. W. (1954). The simultaneous occurrence of benign thymoma and refractory anemia. Blood, $9,935$.

Stibbe, P. D. (1955). Thymoom en aplastische anaemie. Ned. T Geneesk., $99,3782$.

Weinbaum, J. G., and Thompson, R. F. (1955). Erythroblastic hypoplasia associated with thymic tumor and myasthenia gravis. Amer. J. clin. Path., 25, 761. 